Article

\title{
Efficiency Analysis of Zinc Refining Companies
}

\author{
Ha Sung Park, Tae Youn Kim and Daecheol Kim * \\ School of Business, Hanyang University, Seoul 04763, Korea; hscross@naver.com (H.S.P.); \\ unique@hanyang.ac.kr (T.Y.K.) \\ * Correspondence: dckim@hanyang.ac.kr; Tel.: +82-2-2220-1043
}

Received: 10 November 2019; Accepted: 18 November 2019; Published: 19 November 2019

\begin{abstract}
Most global zinc firms consist of multiple refineries with various production capacities. However, it is known that efficiency and Bonus $\mathrm{Zn}$ are mostly dependent on a firm's production capacity. Thus, it is important to examine whether there is knowledge transfer of efficiencies and Bonus $\mathrm{Zn}$ among refineries within the same company, even if their production capacities are quite different. The Data Envelopment Analysis (DEA) is used to measure efficiency scores of forty-two zinc refineries. To examine whether there is a knowledge transfer about efficiency and Bonus $\mathrm{Zn}$ within a firm, a propensity score model is newly applied. Additionally, a regression model is utilized to identify whether this propagation is more effective if refineries are in the same country. It is found that about $86 \%$ of the refineries are inefficient, which indicates that there is much room for refineries to improve their performance. From the result, it is identified that the knowledge of efficiency and Bonus $\mathrm{Zn}$ is transferred within the company. This transfer is particularly influential when both refineries are located in the same country. We also find that firm's revenue can be maximized when efficiency is high and the production capacity and/or Bonus $\mathrm{Zn}$ are significant.
\end{abstract}

Keywords: efficiency; Bonus Zn; environmental regulation; production capacity; data envelopment analysis; propensity score model; zinc refining firms

\section{Introduction}

The recent slowdown of global economic growth, strengthened environmental regulations, and steadily rising energy costs have made the zinc smelting business environment increasingly difficult and competition among companies has intensified [1,2]. Zinc refineries are emphasizing efficiency as a way to survive and further secure a competitive advantage [3]. Borza [4] identified the common interests of efficiency and sustainability by correlating the objectives to reach an optimum level of efficiency with those creating the conditions for economic sustainability. Carley and Spapens [5] addressed that compliance with the future requirements and in order to ensure sustainability, a revolution of production efficiency will be needed.

Recently, companies are also trying to alleviate environmental pollution and environmental issues by reducing resource consumption and cost in the production of products based on eco-efficiency concepts [6,7]. Therefore, in the zinc industry, the efficiency of production and Bonus $\mathrm{Zn}$ are important issues directly related to improving sustainability and solving environmental problems.

The steel industry, which has a manufacturing process and management environment similar to those of the zinc industry, has conducted various studies on efficiency using Data Envelopment Analysis (DEA) to increase efficiency. Lee and Kim [8] analyzed the efficiency and profitability of all twenty-eight major Korean steel companies and presented the target values for becoming efficient companies. Cho and Bae [9] analyzed the efficiency of major steel companies in the world in research beyond Korean steel companies. Through this, they have presented possible reasons for the growth of Korean steel companies. 
As a result of measuring the efficiency of twenty-six Korean steel companies, Shin [10] revealed that domestic steel companies are worse in scale efficiency than pure technology efficiency. This is because small and medium-sized steelmakers have made inefficient investments in steel processing facilities (such as rolling) to achieve economies of scale through expansion of production facilities as competition among companies has intensified.

Choi and Ha [11] used the R \& D expenditure as a proxy variable of technological innovation for three East Asian countries: Korea (45 firms), China (54 firms), and Japan (46 firms). The results showed that the higher the level of innovation activity, the higher the efficiency. The reference company for benchmarking was suggested.

Debbath and Sebastian [12] measured the efficiencies of twenty-two Indian steel companies. As a result of the study, it was argued that the expansion of facilities and the continuous development of technology are necessary to increase efficiency in the Indian steel industry. A number of studies have been conducted on efficiency in the steel industry, which has a similar process and business environment to the zinc industry. However, most studies have been limited to the analysis of the efficiency status of firms and the analysis of changes in efficiency, while failing to identify the factors that affect the efficiency of firms and provide in-depth analysis of the factors.

Lately, Park and Kim [3] not only presented the efficiency status of the East Asian zinc refinery based on data from forty-three East Asian zinc refineries, but also identified the factors affecting efficiency. Their findings show that the capacity of the zinc refinery and Bonus $\mathrm{Zn}$, that represents the refinery's production and process technology capabilities to extract extra zinc, are the factors that influence the efficiency of a refinery. Park and Kim [3] considered only the refineries located in East Asia and did not include refineries owned by East Asian companies but located outside of the region. Thus, by expanding the study of Park and Kim [3] to refineries around the world, we can identify whether cooperation and synergy among refineries belonging to the same company have an influence on efficiency and Bonus $\mathrm{Zn}$ recovery.

There are a number of strategic motivations and objectives for a firm to own and operate multiple peers [13]. Chang and Song [14] addressed that if cooperation is established between these peers in a firm, it enhanced corporate value and product diversification. However, according to a study by Kim and Cho [15], the operation of multiple peers by one corporate structure can be characterized by disadvantages such as difficulty of control rather than synergy effects. Therefore, it can be seen that there are conflicting results in the performance of a firm running multiple peers. In the case of firms operating multiple zinc smelters, the production capacity of smelters in the firm is different. In general, the production capacity of the central smelter is much larger than other smelters in the firm.

When operating refineries with large differences in production capacity, if production capacity has a significant impact on the efficiency of smelters, will synergies result from the operation of these multiple refineries? Will it have a positive impact on efficiency in particular? Because smelters in the firm have different production environments in terms of production capacity that affects their efficiency, even if they belong to the same company, cooperation, or synergy between each other may not appear in efficiency performance. We define a primary refinery as a refinery that has the largest production capacity in a company and the remaining refineries are defined as secondary level refineries. According to Park and Kim [3], the efficiency of the smelter is low when its production capacity is small. Thus, even if the efficiency of the primary smelter in the firm is high, the efficiency of the other small smelters in the firm may be low if the effect of production capacity is applied.

In the meantime, Rhee [16] stated that when the ownership of companies, business organizations, or operating units is transferred to or consolidated with other entities, the larger the size difference between these entities, the higher the post-merger performance. This is because a large company has effective control over small firms, which means that cooperation and technology transfer can be efficient from the large company [17]. However, some argue that the transfer of knowledge is more difficult if the differences within organizations are large [18]. Szulanski [19] studied barriers that make the transfer of knowledge in a company difficult and complex. His findings indicate that the 
major obstacles to knowledge transfer within a firm are the recipients' lack of the ability of knowledge diffusion and the complex relationship between knowledge holders and recipients. Therefore, effective knowledge transfer requires the knowledge holders' ability to diffuse knowledge and the recipients' ability to absorb it [20]. Tang [20] defined the disseminative capacity as the knowledge holders' ability of effectively and efficiently communicating and transmitting knowledge to other members in a network, while the absorptive capacity is the recipients' ability of receiving it. Takii [21] also addressed that knowledge transfers cannot be effective when the recipients do not have sufficient capacity, technologies, or trained people to take in and fully utilize the knowledge. Therefore, the effect of knowledge transfer on large gaps in capacity between organizations has pros and cons.

Since the majority of the zinc refining firms that operate multiple smelters is composed of several small-scale smelters and one or several large ones in terms of production capacity, the results of the study by Rhee [16] can be applied in this case. If this is the case, the spillover effect of transferring knowledge and technologies from the primary refinery to the other refineries in the firm can be expected [14]. The Bonus $\mathrm{Zn}$ represents the amount of zinc extracted in excess of the amount of zinc expected to be contained in the zinc or at the time of its purchase and is determined later by firm's proprietary process technology or methods. Therefore, efficiency and Bonus Zn could be indicators that represent the level of the firm's skills and technologies. In other words, when the efficiency and the amount of additional zinc of the primary refinery in a firm are high, those of the other refineries belonging to the same firm are expected to be higher than those of second level refineries whose primary refinery has low efficiency and Bonus Zn. In addition, if refineries in a firm are located in the same country, the propagation of knowledge would be more effective since these refineries are close in terms of distance, language, and culture [13]. Zaidman [22] and Zaidman and Brock [23] also addressed that it is difficult to transfer knowledge to subsidiaries that exist overseas because of cultural differences. Therefore, it can be expected that there will be a difference in the efficiency of knowledge transfer between smelters in the same area as those who transfer knowledge and subsidiaries abroad.

Thus, in this study, we have two main research questions. First, does the knowledge (such as efficiency and Bonus $\mathrm{Zn}$ ) of the primary refinery propagate to the rest refineries in the same firm even if there are differences in their capacity? Additionally, is this propagation more effective if refineries are in the same country? Second, does this knowledge affect financial performance of the firm? To our knowledge, however, the comparison of efficiency of zinc refineries in the world as well as the spillover effect in the firm has not been studied yet. To measure efficiency of zinc refineries, the slack-based model is used. The propensity score model is applied to identify if there is a propagation of knowledge of efficiency and Bonus $\mathrm{Zn}$ within a firm. Additionally, a regression model is utilized to identify whether this propagation is more effective if refineries are in the same country. Moderated multiple regression model is tried to show the effect of knowledge on firm's financial performance.

\section{DEA Model}

How to measure efficiency can be divided into two major categories: parametric and nonparametric. DEA is a nonparametric method based on the concept of nonparametric efficiency measure proposed by Farrell [24] and the concept of distance function of Shephard [25]. This method is characterized by the ability to consider multiple input and output factors and the ability to measure the efficiency between input and output factors with different specific units of measure.

DEA uses linear programming to derive the most efficient DMU from all the decision-making units (DMU) to be evaluated and then calculate the relative efficiency of the individual DMUs based on this. DEA can be divided into the Charnes, Cooper and Rhodes (CCR) model proposed by Charnes et al. [26] and the Banker, Chames and Cooper (BCC) model developed by Banker et al. [27]. The CCR model is referred to as the constant returns to scale (CRS) model assuming that the ratio of the input and output is constant regardless of the size. The BCC model is called as the variable returns to scale (VRS) model assuming that the ratio of the input and output can vary with the size. 
On the other hand, efficiency is composed of pure technology efficiency and scale efficiency. Since the pure technology efficiency of CCR model and BCC model are the same value, and CCR model represents efficiency when it is optimal in scale, inefficiency due to size can be inferred from the difference between CCR and BCC model. In addition, from the BCC model, whether the DMUs are in the economies of scale or in the diseconomies of scale can be determined when the DMUs are not in the optimal scale.

CCR and BBC models fall into the radial model because inefficient DMUs move in the direction of the origin to become efficient. In the radial model, there is a disadvantage that the distorted efficiency value can be generated even as there are slacks of the input and the output variables. To overcome this problem, Tone [28] proposed Slacks Based Model (SBM) evaluating the efficiency based on slacks. In this study, we utilize the SBM to measure the efficiency and CCR and BCC are used to obtain scale efficiency values. The mathematical formulation of the SBM is presented as follows. Here, we assume that there are J DMUs, $\mathrm{M}$ input resources, and $\mathrm{N}$ output variables.

$$
\theta_{S B M}^{k^{*}}=\min _{\lambda, s^{+}, s^{-}}\left(\frac{1}{M} \sum_{m=1}^{M} \frac{x_{m}^{k}-s_{m}^{-}}{x_{m}^{k}}\right) /\left(\frac{1}{N} \sum_{n=1}^{N} \frac{y_{n}^{k}+s_{n}^{+}}{x_{n}^{k}}\right)
$$

or

$$
\theta_{S B M}^{k^{*}}=\min _{\lambda, s^{+}, s^{-}}\left(1-\frac{1}{M} \sum_{m=1}^{M} \frac{s_{m}^{-}}{x_{m}^{k}}\right) /\left(1+\frac{1}{N} \sum_{n=1}^{N} \frac{s_{n}^{+}}{x_{n}^{k}}\right)
$$

Subject to

$$
\begin{gathered}
x_{m}^{k}=\sum_{j=1}^{J} x_{m}^{j} \lambda^{j}+s_{m}^{-}(m=1,2, \ldots, M) \\
y_{n}^{k}=\sum_{j=1}^{J} y_{n}^{j} \lambda^{j}+s_{n}^{+}(n=1,2, \ldots, N) \\
\sum_{j=1}^{J} \lambda^{j}=1 \\
\lambda^{j} \geq 0(j=1,2, \ldots, J) \\
s_{m}^{-} \geq 0(m=1,2, \ldots, M) \\
s_{n}^{+} \geq 0(n=1,2, \ldots, N)
\end{gathered}
$$

\section{Data Collection and Variable Selection}

\subsection{Data}

In order to measure the efficiency using the DEA, the DMU to be analyzed must first be determined. The DMUs in this study are the world's zinc smelting refineries with capacities of more than 10,000 tons of zinc production. To analyze the efficiency of the zinc smelting firms, we used data from 2014 of Wood Mackenzie, a global energy, metal and mining business consulting firm. The DMU finally used is 66 smelters considering the availability of data.

\subsection{Variable Selection}

In order to utilize DEA meaningfully, the selection of input and output variables is important. One way to choose these variables is to refer to prior studies. In addition, variables could be chosen so that they accurately reflect the organization's key management indicators or objectives $[29,30]$. 
In this study, the input and output variables were determined with consideration of both the previous research [8-12,31,32] and the key management indicators used in zinc refinery industry [3].

First, labor, energy, maintenance, and raw material costs were selected as input variables. Labor costs were used as input variables in previous studies of the zinc and steel industries. Energy, maintenance and raw material costs were selected considering that these are key management indicators of the zinc smelting industry. The output variables used in this study are sales revenue and production volume. These variables are used in almost all industrial studies as well as in the zinc and steel industries. In particular, sales revenue represents qualitative as well as quantitative aspects of management indicators since it includes price and quantity of the product. In general, the number of DMUs should be at least three times larger than the sum of the number of input and output variables. In this study, this condition is satisfied since we have forty-two DMUs with fifteen primary refineries. The average capacity of the primary and second level refineries is $281.40 \mathrm{kt}$ and $143.63 \mathrm{kt}$, respectively. As you can see, there are significant differences between primary and secondary level refineries. The descriptive statistics of input and output variables used in this study are summarized in Table 1.

Table 1. Descriptive statistics of input and output variables.

\begin{tabular}{|c|c|c|c|c|c|c|c|c|}
\hline & \multicolumn{4}{|c|}{ Input Variables } & \multicolumn{2}{|c|}{ Output Variables } & \multicolumn{2}{|c|}{ Capacity } \\
\hline & Labor & Energy & Maintenance & $\begin{array}{c}\text { Raw } \\
\text { Material }\end{array}$ & $\begin{array}{c}\text { Sales } \\
\text { Revenue }\end{array}$ & $\begin{array}{l}\text { Production } \\
\text { Volume }\end{array}$ & Primary & $\begin{array}{l}\text { Second } \\
\text { Level }\end{array}$ \\
\hline & $000 \mathrm{U \$}$ & $000 \mathrm{U \$}$ & $000 \mathrm{U \$}$ & $000 \mathrm{U \$}$ & $000 \mathrm{U \$}$ & kt & kt & kt \\
\hline Max. & $1,098,137$ & $1,629,518$ & 326,822 & $6,783,104$ & $5,243,147$ & 1119 & 560 & 360 \\
\hline Min. & 2759 & 4304 & 540 & 12,730 & 13,225 & 12 & 100 & 20 \\
\hline Mean. & 112,361 & 213,205 & 44,310 & 913,304 & 700,736 & 269 & 281.40 & 143.63 \\
\hline $\begin{array}{l}\text { Standard } \\
\text { Deviation }\end{array}$ & 228,456 & 377,415 & 77,064 & $1,666,122$ & $1,304,119$ & 294 & 151.75 & 80.20 \\
\hline
\end{tabular}

\subsection{DEA Models}

As introduced earlier, in this study, SBM is used to measure the efficiency, and CCR and BCC models are utilized to calculate the scale efficiency. Traditionally, CCR and BBC models have been most frequently used to measure efficiency since they were the first models developed and are easy to understand and use. In the case of these radial methods, the efficiency value is one even in the presence of the slack variables, which is not correct. The SBM has been recently developed as a non-radial method to overcome this weakness of these radial models [28].

\subsection{Regression Model}

To analyze the factors that affect the outcome of DEA, the Tobit regression model has generally been used because the range of efficiency scores of DEA is bounded between zero and one [33]. However, many recent studies addressed that models generate almost identical results since these efficiency scores are only fractional data [34]. Thus, in this study, the following regression model is used to analyze the effect of location on transferring knowledge within a firm.

$$
\mathrm{SEff} i=\alpha+\beta_{1} \mathrm{PEff}_{j}+1 \operatorname{Loc}_{i j}+\varepsilon_{\mathrm{ij}}
$$

where, $\mathrm{S}$ Eff $f_{\mathrm{i}}$ represents the second level DMU ${ }_{i}$ 's efficiency score obtained from DEA. P Eff $f_{\mathrm{j}}$ is the efficiency score of the primary $j$. Note that $\mathrm{DMU}_{i}$ and $\mathrm{DMU}_{j}$ are in the same firm. 1 Loc shows whether the primary and second level refineries are located in the same country. Thus, if the secondary level refinery $i$ and the associated primary refinery $j$ are located in the same country, the 1Loc variable has one. Otherwise, it has zero value. 


\subsection{Propensity Scores}

To test if primary refineries' know-how leads to secondaries' efficiency and Bonus Zn performance, a propensity-score model is used. By this approach, it is possible to control covariates with a propensity score so that an effect of the variable of interest on the dependent variable could only be examined. The basic advantage of this approach is that instead of matching directly on multiple dimensions, we match high-efficient and low-efficient firms based on a one-dimensional summary variable: the probability of being included in treatment group as predicted by the matching characteristics (also called as a propensity score) [35]. In this study, we follow the following steps to test the dissemination of knowledge from the primary to secondary level refineries.

First, a logistic regression model of dissemination with a capacity as a covariate. Based on the model, we calculate the propensity score for all secondary level refineries. Next, we sort secondary level refineries based on their propensity scores and run the nearest matching algorithm. Finally, we conduct $t$-tests for differences in means between secondary level refineries with high performance (efficiency and Bonus $\mathrm{Zn}$ ) primary refineries and secondary level refineries with low performance (efficiency and Bonus $\mathrm{Zn}$ ) primary refineries.

\section{Results}

\subsection{Efficiency Scores}

In this study, to analyze the efficiency of the scale of the zinc refineries, we used the output-based CCR and the BCC models, and for the efficiency the SBM model was used. The results are shown in Table 2.

The first column of Table 2 shows the DMU. The bold DMU numbers indicate they are primary refineries. The second column is the result of the CCR model measured under the assumption of constant return to scale revenue and represents the overall technical efficiency (TE). In the CCR model, two refineries were found to be efficient, and the remaining forty refineries were relatively inefficient DMUs. The next column indicates the results of the BCC model, which represents pure technical efficiency (PTE). In the BCC model, nine efficient refineries were identified, and the remaining thirty-three DMUs were inefficient. Scale efficiency (SE) is shown in the fourth column and two DMUs are efficient in scale. Scale efficiency can be obtained from dividing the result of CCR by that of BCC.

The fifth and the sixth columns indicate the cause of the inefficiency. If technical or scale inefficiency is the reason, the fifth or sixth column is bold pointed, respectively. If technical inefficiency is the cause, the DMU should consider the improvement in technical matters such as knowledge of processes and/or technologies and product development. If scale inefficiency is the cause, the amounts of inputs should be adjusted to the proper volumes of energy, maintenance, and raw materials to be efficient. From the results, we can see that most DMUs (thirty-one out of forty-two) need improvement in their technical efficiency rather than scale adjustment. It is also found that two largest refineries (Korea Zinc in Korea and Glencore in Spain) in terms of their capacity turn out to be efficient and the smallest DMU in our study shows the lowest efficiency as expected. This also tells that the production capacity is one of the most important factors in efficiency.

The seventh column gives information on whether the yield per unit will increase or decrease as the refinery is scaled up. Constant return-to-scale (Constant) means that the current scale is optimal. Therefore, there is no need to scale up or down, and the two largest DMUs also belong to this group. However, most DMUs are in "Decreasing", which suggests that the output gained for the current input is in a low efficiency state and therefore the scale can be reduced to increase the efficiency. On the contrary, DMUs in "Increasing" can be increased in scale so that they can get higher return ratio. The last column shows efficiency score obtained from the SBM, where nine refineries are efficient and the remaining thirty-three refineries are inefficient. The average efficiency score of the total refineries studied is as low as 0.44 , which represents that most refineries need improvement. The average efficiency of the primary refineries is shown to be 0.62 and that of the secondary level refineries is 0.27 . 
As you can see, the primary refineries are much more efficient that those of their secondary level refineries. This also implies that production capacity could be one of key factors in refinery efficiency.

Table 2. Efficiency scores of decision-making units (DMUs).

\begin{tabular}{|c|c|c|c|c|c|c|c|}
\hline \multirow{2}{*}{ DMU } & \multirow{2}{*}{$\begin{array}{c}\text { CCR } \\
\text { TE }\end{array}$} & \multirow{2}{*}{$\begin{array}{l}\text { BCC } \\
\text { PTE }\end{array}$} & \multirow{2}{*}{$\begin{array}{c}\text { Scale } \\
\text { SE (TE/PTE) }\end{array}$} & \multicolumn{2}{|c|}{ Cause of Inefficiency } & \multirow{2}{*}{ RTS } & \multirow{2}{*}{ SBM } \\
\hline & & & & PTE & SE & & \\
\hline 1 & 0.675 & 0.678 & 0.996 & 0 & & Decreasing & 0.574 \\
\hline 2 & 0.655 & 0.678 & 0.967 & 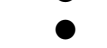 & & Increasing & 0.524 \\
\hline 3 & 0.672 & 0.730 & 0.921 & 0 & & Decreasing & 0.498 \\
\hline 4 & 0.174 & 0.488 & 0.356 & & - & Decreasing & 0.035 \\
\hline 5 & 0.490 & 0.637 & 0.770 & $\bullet$ & & Decreasing & 0.132 \\
\hline 6 & 0.476 & 0.488 & 0.975 & 0 & & Decreasing & 0.239 \\
\hline 7 & 0.471 & 0.489 & 0.964 & 0 & & Increasing & 0.330 \\
\hline 8 & 0.383 & 0.562 & 0.680 & 0 & & Decreasing & 0.119 \\
\hline 9 & 0.481 & 0.612 & 0.786 & $\bullet$ & & Decreasing & 0.250 \\
\hline 10 & 0.498 & 0.638 & 0.780 & $\bullet$ & & Decreasing & 0.273 \\
\hline 11 & 0.464 & 0.564 & 0.822 & $\bullet$ & & Decreasing & 0.246 \\
\hline 12 & 1.000 & 1.000 & 1.000 & & & Constant & 1.000 \\
\hline 13 & 0.708 & 1.000 & 0.708 & & - & Increasing & 1.000 \\
\hline 14 & 0.321 & 0.623 & 0.515 & & - & Decreasing & 0.122 \\
\hline 15 & 0.714 & 0.741 & 0.963 & • & & Increasing & 0.233 \\
\hline 16 & 0.741 & 0.821 & 0.902 & $\bullet$ & & Increasing & 0.658 \\
\hline 17 & 0.682 & 1.000 & 0.682 & & 0 & Increasing & 1.000 \\
\hline 18 & 0.555 & 0.747 & 0.743 & & 0 & Decreasing & 0.163 \\
\hline 19 & 0.374 & 0.453 & 0.825 & $\bullet$ & & Decreasing & 0.044 \\
\hline 20 & 0.443 & 0.524 & 0.845 & 0 & & Decreasing & 0.265 \\
\hline 21 & 0.409 & 0.595 & 0.686 & - & & Decreasing & 0.090 \\
\hline 22 & 0.216 & 0.444 & 0.486 & - & & Decreasing & 0.120 \\
\hline 23 & 1.000 & 1.000 & 1.000 & & & Constant & 1.000 \\
\hline 24 & 0.894 & 1.000 & 0.894 & & - & Increasing & 1.000 \\
\hline 25 & 0.485 & 0.540 & 0.898 & $\bullet$ & & Decreasing & 0.406 \\
\hline 26 & 0.598 & 0.774 & 0.773 & & • & Decreasing & 0.178 \\
\hline 27 & 0.516 & 0.560 & 0.921 & • & & Decreasing & 0.193 \\
\hline 28 & 0.758 & 1.000 & 0.758 & & 0 & Increasing & 1.000 \\
\hline 29 & 0.650 & 0.716 & 0.907 & $\bullet$ & & Decreasing & 0.373 \\
\hline 30 & 0.616 & 0.672 & 0.916 & $\bullet$ & & Decreasing & 0.532 \\
\hline 31 & 0.700 & 0.703 & 0.996 & 0 & & Increasing & 0.553 \\
\hline 32 & 0.589 & 0.611 & 0.964 & - & & Decreasing & 0.299 \\
\hline 33 & 0.487 & 0.583 & 0.836 & $\bullet$ & & Decreasing & 0.412 \\
\hline 34 & 0.822 & 1.000 & 0.822 & & 0 & Increasing & 1.000 \\
\hline 35 & 0.731 & 1.000 & 0.731 & & $\bullet$ & Increasing & 1.000 \\
\hline 36 & 0.796 & 0.796 & 0.999 & 0 & & Increasing & 0.445 \\
\hline 37 & 0.432 & 0.576 & 0.751 & 0 & & Decreasing & 0.132 \\
\hline 38 & 0.724 & 0.808 & 0.896 & $\bullet$ & & Decreasing & 0.666 \\
\hline 39 & 0.260 & 0.497 & 0.524 & - & & Decreasing & 0.148 \\
\hline 40 & 0.935 & 1.000 & 0.935 & & 0 & Increasing & 1.000 \\
\hline 41 & 0.489 & 0.544 & 0.899 & 0 & & Decreasing & 0.212 \\
\hline 42 & 0.479 & 0.581 & 0.825 & • & & Decreasing & 0.155 \\
\hline Mean & 0.585 & 0.702 & 0.824 & & $\begin{array}{l}\text { nary: } 0 \\
d \text { level }\end{array}$ & & 0.440 \\
\hline
\end{tabular}

\subsection{Propagation of Knowledge from the Primary to the Secondary Level Refineries}

To investigate whether knowledge could be transferred among refineries within the firm, a propensity score method is used to reduce bias in comparing a treatment group to a non-randomized control group. 


\subsubsection{Efficiency}

One of objectives of the study is to examine if the efficiency knowledge can be shared among the refineries in the firm. To do this, primary refineries, whose efficiency scores are larger than the median of all primary refineries, are classified as a treatment group and the others belong to a control group. A logistic regression model of a primary refinery is estimated. The covariates are the firm's production capacity and revenue. The predicted probability of the primary refinery, referred to as propensity score, is calculated. The caliper matching is used to secure homogeneity, with similar propensity scores between the treatment group and the control group for covariates. The results of caliper matching are shown in Table 3. As can be seen in Table 3, nineteen companies in the treatment group and eleven in the control group are matched, and the average differences in capacity and revenue are decreased $73 \%$ and $76 \%$, respectively.

Table 3. Matching results for efficiency.

\begin{tabular}{|c|c|c|c|c|c|c|c|c|}
\hline & \multicolumn{4}{|c|}{ Before Matching } & \multicolumn{4}{|c|}{ After Matching } \\
\hline & \multicolumn{2}{|c|}{ Average } & \multirow[b]{2}{*}{$p$-Value } & \multirow[b]{2}{*}{$\begin{array}{l}\text { Standardized } \\
\text { Difference }\end{array}$} & \multicolumn{2}{|c|}{ Average } & \multirow[b]{2}{*}{$p$-Value } & \multirow[b]{2}{*}{$\begin{array}{l}\text { Standardized } \\
\text { Difference }\end{array}$} \\
\hline & $\begin{array}{l}\text { Control } \\
\text { Group } \\
(n=23)\end{array}$ & $\begin{array}{c}\text { Treatment } \\
\text { Group } \\
(\mathrm{n}=19)\end{array}$ & & & $\begin{array}{l}\text { Control } \\
\text { Group } \\
(n=11)\end{array}$ & $\begin{array}{l}\text { Treatment } \\
\text { Group } \\
(\mathrm{n}=19)\end{array}$ & & \\
\hline Capacity & 148.826 & 246.737 & 0.014 & 0.006853 & 178.000 & 246.737 & 0.179 & 0.004119 \\
\hline Revenue & 43.174 & 41.842 & 0.601 & -0.020423 & 41.364 & 41.842 & 0.871 & 0.007667 \\
\hline $\mathrm{S}$ eff & 0.283 & 0.637 & 0.001 & & 0.246 & 0.637 & 0.000 & \\
\hline
\end{tabular}

A $t$-test is conducted to examine the propagation of know-how about efficiency within the firm. As in Table 4, the mean difference between the two groups can be judged to be statistically significant at the significance level of $0.000(p<0.01)$. Therefore, it can be said that the knowledge related to efficiency could be shared among all refineries in a firm.

Table 4. Result of the $t$-test.

\begin{tabular}{ccccccc}
\hline & \multicolumn{2}{c}{ Average } & \multicolumn{2}{c}{ Standard Deviation } & & \\
\cline { 2 - 6 } & $\begin{array}{c}\text { Control Group } \\
(\mathbf{n}=\mathbf{1 1})\end{array}$ & $\begin{array}{c}\text { Treatment Group } \\
(\mathbf{n}=\mathbf{1 9})\end{array}$ & $\begin{array}{c}\text { Control Group } \\
(\mathbf{n}=\mathbf{1 1})\end{array}$ & $\begin{array}{c}\text { Treatment Group } \\
(\mathbf{n}=\mathbf{1 9})\end{array}$ & $\boldsymbol{t}$ & $\boldsymbol{p}$-Value \\
\hline S eff & 0.246 & 0.637 & 0.164 & 0.352 & 4.133 & 0.000 \\
\hline
\end{tabular}

\subsubsection{Bonus $\mathrm{Zn}$}

The next objective of the study is to examine if the knowledge about Bonus $\mathrm{Zn}$ can be shared among the refineries in a firm. To do this, primary refineries, whose amounts of Bonus $\mathrm{Zn}$ are larger than the median of all primary refineries' Bonus $\mathrm{Zn}$ amounts, are classified as a treatment group, and other refineries in the firm are included in a control group. A logistic regression model of primary refinery is estimated. The covariates are the firm's production capacity and revenue. The propensity score of the primary refinery is calculated. The caliper matching is used to secure homogeneity between the treatment group and the control group. Table 5 shows the results of caliper matching. As shown in the table, eighteen companies in the treatment group and eleven in the control group are matched, and the average differences in capacity and revenue are decreased $44 \%$ and $49 \%$, respectively. 
Table 5. Matching results for Bonus Zn.

\begin{tabular}{|c|c|c|c|c|c|c|c|c|}
\hline & \multicolumn{4}{|c|}{ Before Matching } & \multicolumn{4}{|c|}{ After Matching } \\
\hline & \multicolumn{2}{|c|}{ Average } & \multirow[b]{2}{*}{$p$-Value } & \multirow[b]{2}{*}{$\begin{array}{l}\text { Standardized } \\
\text { Difference }\end{array}$} & \multicolumn{2}{|c|}{ Average } & \multirow[b]{2}{*}{$p$-Value } & \multirow[b]{2}{*}{$\begin{array}{c}\text { Standardized } \\
\text { Difference }\end{array}$} \\
\hline & $\begin{array}{l}\text { Control } \\
\text { Group } \\
(n=24)\end{array}$ & $\begin{array}{c}\text { Treatment } \\
\text { Group } \\
(\mathrm{n}=18)\end{array}$ & & & $\begin{array}{l}\text { Control } \\
\text { Group } \\
(n=11)\end{array}$ & $\begin{array}{c}\text { Treatment } \\
\text { Group) } \\
(\mathrm{n}=18)\end{array}$ & & \\
\hline Capacity & 176.000 & 215.944 & 0.316 & 0.002437 & 190.273 & 215.944 & 0.626 & 0.001417 \\
\hline Revenue & 40.792 & 44.944 & 0.100 & 0.066209 & 40.545 & 44.944 & 0.200 & 0.054340 \\
\hline Bonus Zn & 12.458 & 15.389 & 0.002 & & 11.545 & 15.389 & 0.002 & \\
\hline
\end{tabular}

A $t$-test is conducted to examine the propagation of know-how about Bonus $\mathrm{Zn}$ within the firm. As can be seen in Table 6, the mean difference between the two groups can be determined to be statistically significant at the significance level of $0.002(p<0.01)$. Thus, it can be said that knowledge about Bonus $\mathrm{Zn}$ could be spread among the entire refineries in a firm.

Table 6. Result of the $t$-test.

\begin{tabular}{ccccccc}
\hline & \multicolumn{2}{c}{ Average } & \multicolumn{2}{c}{ Standard Deviation } & & \\
\cline { 2 - 6 } & $\begin{array}{c}\text { Control Group } \\
(\mathbf{n}=\mathbf{1 1})\end{array}$ & $\begin{array}{c}\text { Treatment Group } \\
(\mathbf{n}=\mathbf{1 8})\end{array}$ & $\begin{array}{c}\text { Control Group } \\
(\mathbf{n}=\mathbf{1 1})\end{array}$ & $\begin{array}{c}\text { Treatment Group } \\
(\mathbf{n}=\mathbf{1 8})\end{array}$ & $\boldsymbol{t}$ & $\boldsymbol{p}$-Value \\
\hline Bonus Zn & 11.55 & 15.39 & 1.864 & 3.483 & 3.361 & 0.002 \\
\hline
\end{tabular}

\subsubsection{Location}

We examine the importance of distance proximity that distinguishes between the international and domestic relationships. We augment the previous model by introducing a dummy variable, 1Loc that has one if the primary and secondary level are located in the same country, and zero otherwise.

$$
S \text { Eff }_{\mathrm{i}}=\alpha+\beta_{1} \mathrm{PEff}_{j}+1 \operatorname{Loc}_{i j}+\varepsilon_{\mathrm{ij}}
$$

From the result in Table 7, we can see that the propagation of knowledge would be more effective. This result is because these refineries are close in terms of distance, language, and culture so there are fewer difficulties in communication among these refineries.

Table 7. Result of the regression model.

\begin{tabular}{cccccc}
\hline & B & Standard Error & Standardized & $t$ & $p$-Value \\
\hline (intercept) & -0.275 & 0.223 & & -1.234 & 0.225 \\
P eff & 0.745 & 0.15 & 0.689 & 4.951 & 0 \\
1 Loc & 0.205 & 0.153 & 0.311 & 1.997 & 0.053 \\
\hline
\end{tabular}

\subsection{Relationship between Revenue and Efficiency with Respect to Production Capacity or Bonus Zn}

Figure 1 shows the relationship between revenue, efficiency, production capacity or Bonus Zn. In Figure 1a, the relationship between revenue, efficiency, and production capacity is shown. X-and Y-axes represent production capacity level and revenue, respectively, while two lines are classified based on the level of efficiency. As can be seen from the figure, the difference in revenue according to the production capacity is not large for the low efficiency group, but for the high efficiency group, the difference in revenue is large according to the production capacity. Therefore, the efficiency could be moderating the effect of firm's production capacity on their revenue. In addition, when firms' production capacities are low, there are a little difference in revenue between the high efficiency and low efficiency groups. That is, when the firm's production capacity is low, the level of firm's efficiency has no effect on their revenue. At the high production capacity level, however, the revenue of the firm with high efficiency is much higher than that of the firm with low efficiency. This result is consistent 
with the results of Wei et al. [36] who studied the effect of production capacity on the revenue of steel company.

In Figure $1 b$, the relationship between revenue, efficiency, and Bonus $\mathrm{Zn}$ is represented. The level of Bonus $\mathrm{Zn}$ and revenue are shown on the $\mathrm{X}$ - and Y-axes, respectively, with two classified lines based on the level of efficiency. As can be seen, the revenue differences between firms with low and high efficiency according to Bonus $\mathrm{Zn}$ are small, but for the high efficiency group, the revenue difference is large according to Bonus Zn. Thus, the efficiency could moderate the effect of firm's Bonus Zn on their revenue as in the case of production capacity. Additionally, when the firm's level of Bonus $\mathrm{Zn}$ is low, there is a little revenue difference between two different efficiency groups. In other words, if the firm's level of Bonus $\mathrm{Zn}$ is low, the firm's efficiency level has no effect on their revenue. In the case of high level of Bonus $\mathrm{Zn}$, however, the revenue of high efficiency group is much larger than that of the low efficient firm.

From Figure 1a,b, we can see that efficiency, production capacity, and Bonus Zn are important factors in revenue. It is also found that firm's revenue can be maximized when the efficiency is high and production capacity and/or Bonus $\mathrm{Zn}$ are large.

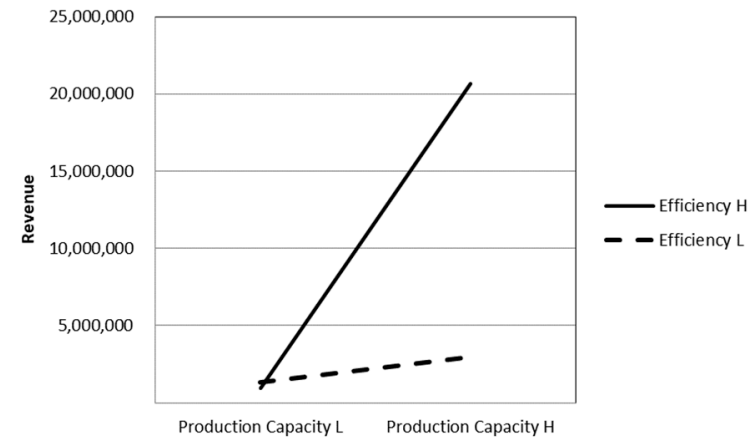

(a)

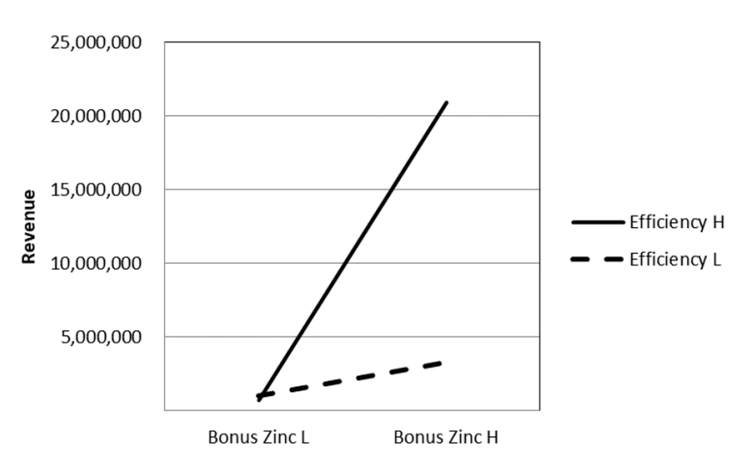

(b)

Figure 1. Revenue difference between two different efficiency levels: (a) according to two production capacity levels; (b) according to two Bonus Zn levels.

\section{Conclusions}

In this study, we examined the efficiency of forty-two zinc refineries in the world. Each refinery belongs to one of fifteen firms. It is found that about $86 \%$ of the refineries are inefficient and overall average efficiency score is about 0.44 , which indicates that there is much room for refineries to improve their performance. Each firm has a number of refineries, most of which consist of one large refinery and remaining smaller ones. We find that the overall average efficiency of each firm's largest refinery is 0.62 , and the overall average efficiency of the other remaining refineries is 0.27 . These results show that the difference in efficiency between the primary refinery of each company and the other refineries is large. This may be due to differences in the production capacity of refineries [3].

On the other hand, as a result of analyzing whether the knowledge about efficiency is spread within the company, it can be seen that this information is shared within the company at the significance level of $1 \%$. In general, if there are subsidiaries of the same industry within a company and a large difference in size between them, then it is known that they are easily controlled by the larger company. In the case of zinc refineries, the difference in size between refineries in a firm is large, so that it is easy to control and spread the knowledge among them, and thus can be interpreted as to show these results. In addition, since production capacity is an important factor in the efficiency of a zinc refinery, knowledge about efficiency may be difficult to spread within a company if production capacity differs. However, these results reveal that this information can be transferred from the primary refinery to the other refineries in a firm despite differences in production capacity. 
Similarly, knowledge about Bonus Zn spreads within a company, which is statistically significant at $5.3 \%$ significance level. The transfer of this knowledge within a firm is particularly influential when both smelters are located in the same country.

Therefore, the strategy of focusing innovation efforts on the most competent smelters in the firm first and then transferring the knowledge to other small refineries seems desirable. In addition, considering the merger with the other zinc refineries, more efficient transfer of this knowledge is possible if the refineries are located in the same country.

The relationship between revenue, efficiency, and production capacity was examined. From the result, we find that the efficiency could moderate the effect of the firm's production capacity in regards to their revenue. This result is consistent with the results of Wei et al. [36] who studied the effect of production capacity on the revenue of steel companies. In addition, the relationship between revenue, efficiency, and Bonus Zn is also represented. Similarly, we show that the efficiency could moderate the effect of firm's Bonus $\mathrm{Zn}$ on their revenue as in the case of production capacity. From these results, it is found that firm's revenue can be maximized when the efficiency is high and production capacity and/or Bonus $\mathrm{Zn}$ is large.

As an academic contribution of this study, the current status of efficiency of global zinc refineries are presented, and the direction of efficiency improvement is suggested through the difference in efficiency between the primary refinery and the remaining refineries in a firm. In addition, for the first time, the characteristics of zinc refinery firms are identified in terms of production capacity, and the fact that know-how in efficiency and Bonus Zn recovery could be shared within the firm are revealed even if there is a big difference in production capacity between primary and the rest refineries in a firm. In this study, the propensity-score matching model is newly applied to test whether primary refineries' knowledge lead secondary refinery's efficiency and Bonus Zn performance. This approach has an advantage of controlling covariates with a propensity score so that only an effect of the variable of interest on the dependent variable could be identified. In addition, the effects of the efficiency and Bonus $\mathrm{Zn}$ on the firm's revenue are examined by the level of production capacities of refineries.

As a contribution to practical application, the strategy of resource and capacity allocation between the primary refinery and the other refineries in a firm is suggested to improve the innovation capability such as efficiency and Bonus $\mathrm{Zn}$ of the firm $[37,38]$. In addition, a strategy is given to consider refineries in the same country for more efficient transfer of corporate knowledge when merging other refineries.

This study used 2014 data from Wood Mackenzie, a metal and mining business-consulting firm. However, given the current date of 2019, some time lag occurs. The results of knowledge transfer based on 2014 data may yield different results over time. Therefore, this is the limitation of this research and can be the subject of future research.

In the future, panel data could be used to study changes in efficiency according to time and technology development and the effects of the merger of zinc refineries. In addition, it is necessary to analyze in detail the reason or backgrounds of the current strategy or business environment to add refineries with small production capacity in expanding the firm even if the production capacity is one of the most important factors in efficiency and Bonus Zn.

Author Contributions: Conceptualization, H.S.P. and D.K.; data collection, H.S.P.; data analysis and propensityscore model conduction, H.S.P. and T.Y.K.; writing, H.S.P. and D.K.

Funding: This research was funded by Hanyang University, grant number HY-2019.

Conflicts of Interest: The authors declare no conflict of interest.

\section{References}

1. Kim, D.H. 2016 Industry Risk Rating-Nonferrous Metal. Available online: http://www.nicerating.com/ common/pdfViewer.do?docId=1L5TH2jcsqQ (accessed on 16 November 2018).

2. Yun, J.J. How do we conquer the growth limits of capitalism? Schumpeterian Dynamics of Open Innovation. J. Open Innov. Technol. Mark. Complex. 2015, 1, 17-20. [CrossRef] 
3. Park, H.S.; Kim, D.C. Efficiency Analysis of East Asian Zinc Smelters and Effects of Capacity and Bonus Zn on Efficiency. J. Open Innov. Technol. Mark. Complex. 2019, 5, 4. [CrossRef]

4. Borza, M. The Connection between Efficiency and Sustainability-A Theoretical Approach. Procedia Econ. Finance 2014, 15, 1355-1363. [CrossRef]

5. Carley, M.; Spapens, P. Condividere il Mondo: Equità e Sviluppo Sostenibile nel Ventunesimo Secolo; Edizione Ambiente: Milano, Italy, 1999; p. 90.

6. Ehrenfeld, J.R. Eco-efficiency: Philosophy, Theory, and Tools. J. Ind. Ecol. 2005, 9, 6-8. [CrossRef]

7. Yadong, Y. Eco-efficiency trends in China, 1978-2010: Decoupling environmental pressure from economic growth. Ecol. Indic. 2013, 24, 177-184.

8. Lee, H.S.; Kim, K.S. Measuring efficiency of Korean steel industry employing DEA. J. Korea Contents Assoc. 2007, 7, 195-205. [CrossRef]

9. Cho, B.; Bae, G.H. Efficiency and Total Factor Productivity of North-East Asian Countries' Steel Industries; The Northeast Asia Economic Association of Korea: Seoul, Korea, 2008; Vol. 20, pp. 1-24.

10. Shin, Y.S. The efficiency analysis of export-oriented steel companies using DEA model. J. Int. Trade Commer. 2012, 8, 119-137. [CrossRef]

11. Choi, S.B.; Ha, G.R. A study on the management efficiency with technological innovation factors: An comparative analysis of Korean, Japanese and Chinese steel industry firms. KJBA 2013, 26, 1887-1908.

12. Debbath, R.M.; Sebastian, V.J. Efficiency in the Indian iron and steel industry-An application of data envelopment analysis. JAMR 2014, 11, 4-19.

13. Suh, E.K.; Lee, S.C.; Koo, J. The Strategic M\&A Approach based on the Leading SME (Small-Medium Enterprise)'s PMI (Post-Merger Integration) Failure Case. J. Strateg. Manag. 2014, 17, 51-69.

14. Chang, Y.K.; Song, I.M. An Empirical Study of Merger Motives in Korea. Korean Manag. Rev. 1991, 20 , 1-37.

15. Kim, K.Y.; Cho, H.S. An Empirical Study on the Corporate Merger Effects in Korea. Korean J. Financ. Stud. 1996, 19, 1-26.

16. Rhee, Y.P. Post Merger Integration Key Success Factor: PEF (Private Equity Fund) Cross border M\&A Cases. Korean Manag. Cons. Rev. 2016, 16, 203-212.

17. Cusatis, P. Why can't we predict Merger and Acquisition Success? An Analysis and Preliminary Test of a New Approach. SBEJ 2009, 32, 79-112.

18. Kowalska-Styczeń, A.; Malarz, K.; Paradowski, K. Model of Knowledge Transfer Within an Organisation. J. Artif. Soc. Soc. Simul. 2018, 21,1-28. [CrossRef]

19. Szulanski, G. Exploring internal stickiness: Impediments to the transfer of best practice within the firm. Strat. Manag. J. 1996, 17, 27-43. [CrossRef]

20. Tang, F. Knowledge transfer in intra-organization networks. Syst. Res. Behav. Sci. 2011, 28, $270-282$. [CrossRef]

21. Takii, S. Productivity spillovers and characteristics of foreign multinational plants in Indonesian manufacturing 1990-1995. J. Dev. Econ. 2005, 76, 521-542. [CrossRef]

22. Zaidman, N. Cultural codes and language strategies in business communication interactions between Israeli and Indian businesspeople. MCQ 2001, 14, 408-441.

23. Zaidman, N.; Brock, D.M. Knowledge transfer within multinationals and their foreign subsidiaries: A culturecontext approach. Group Organ. Manag. 2009, 34, 297-329. [CrossRef]

24. Farrell, M.J. The Measurement of Productive Efficiency. J. R. Stat. Soc. Ser. A (General) 1957, $120,253$. [CrossRef]

25. Shephard, R. Theory of Cost and Production Function; Princeton University Press: Princeton, NJ, USA, 1970; pp. 64-78.

26. Charnes, A.; Cooper, W.; Rhodes, E. Measuring the efficiency of decision making units. Eur. J. Oper. Res. 1978, 2, 429-444. [CrossRef]

27. Banker, R.D.; Charnes, A.; Cooper, W.W. Some Models for Estimating Technical and Scale Inefficiencies in Data Envelopment Analysis. Manag. Sci. 1984, 30, 1078-1092. [CrossRef]

28. Tone, K. A slacks-based measure of efficiency in data envelopment analysis. Eur. J. Oper. Res. 2001, 130, 498-509. [CrossRef]

29. Ko, K.; Kim, D. The Analyses of the Operational Efficiency and Efficiency Factors of Retail Stores Using DEA Model. Korean Manag. Sci. Rev. 2014, 31, 135-150. [CrossRef] 
30. Donthu, N.; Yoo, B. Retail productivity assessment using data envelopment analysis. J. Retail. 1998, 74, 89-105. [CrossRef]

31. Shao, L.; He, Y.; Feng, C.; Zhang, S. An empirical analysis of total-factor productivity in 30 sub-sub-sectors of China's nonferrous metal industry. Resour. Policy 2016, 50, 264-269. [CrossRef]

32. Shao, Y.; Wang, S. Productivity growth and environmental efficiency of the nonferrous metals industry: An empirical study of China. J. Clean. Prod. 2016, 137, 1663-1671. [CrossRef]

33. Tobin, J. Estimation of Relationships for Limited Dependent Variables. Econometrica 1958, 26, 24-36. [CrossRef]

34. Puig-Junoy, J. Partitioning input cost efficiency into its allocative and technical components: An empirical DEA application to hospitals. Socio-Economic Plan. Sci. 2000, 34, 199-218. [CrossRef]

35. Hochberg, Y.V.; Sapienza, P.; Vissing-Jørgensen, A.; Vissing-Jørgensen, A. A Lobbying Approach to Evaluating the Sarbanes-Oxley Act of 2002. J. Account. Res. 2009, 47, 519-583. [CrossRef]

36. Wei, P.; Tang, H.-Q.; Chen, Y.; Chen, X.-H. Measuring technical efficiency of Chinese nonferrous metals enterprises on a background of industry consolidation. Trans. Nonferrous Met. Soc. China 2013, 23, 2797-2806. [CrossRef]

37. Leydesdorff, L.; Ivanova, I. "Open innovation" and "triple helix" models of innovation: Can synergy in innovation systems be measured? J. Open Innov. Technol. Mark. Complex. 2016, 2, 11-12. [CrossRef]

38. Schiuma, G.; Lerro, A. The business model prism: Managing and innovating business models of arts and cultural organization. J. Open Innov. Technol. Mark. Complex. 2017, 3, 13. [CrossRef]

(C) 2019 by the authors. Licensee MDPI, Basel, Switzerland. This article is an open access article distributed under the terms and conditions of the Creative Commons Attribution (CC BY) license (http://creativecommons.org/licenses/by/4.0/). 